
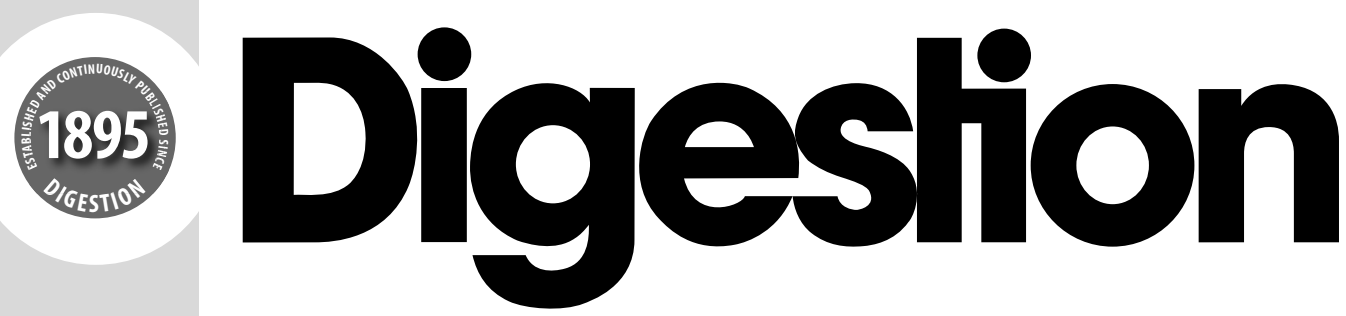

\title{
International Journal of Gastroenterology
}

Founded as 'Archiv für Verdauungskrankheiten' 1895 by I. Boas

Continued as 'Gastroenterologia' 1939-1967

Former Editors: P. Morawitz (1934-1936), R. Staehelin (1937-1943), A. Hurst (1940-1945),

W. Löffler (1943-1961), T.C. Hunt (1947-1967), N. Henning (1953-1962), B. Ihre (1953-1967),

H. Bartelheimer (1963-1967), M. Demole (1963-1971), H. Kapp (1968-1970),

R. Lambert (1972-1978), W. Creutzfeldt (1979-1992), R. Arnold (1993-2003),

C. Beglinger (2004-2011), B. Göke (2004-2014)

\section{Editors-in-Chief}

V. Ellenrieder, Göttingen

Y. Shinomura, Sapporo

Managing Editors

S. Cameron, Göttingen

U. König, Göttingen

\section{Associate Editors}

A. Andoh, Otsu

A. Canbay, Essen

K. Higuchi, Osaka

R. Jakobs, Ludwigshafen

Y. Kinoshita, Izumo

A. F. König, Göttingen

N. Malek, Tübingen

P.J. Michl, Halle (Saale)

A. Nakajima, Yokohama

G. Rogler, Zurich

Y. Sasaki, Kumamoto

T. Takayama, Tokushima

M. Tanaka, Fukuoka

A. Vogel, Hannover

\section{Editorial Board}

A. Amanzada, Göttingen

W. Fischbach, Aschaffenburg

J. Gaedcke, Göttingen

G. Holtmann, Brisbane, Qld.

F. Itoh, Kawasaki

F. Kolligs, Berlin

F. Lordick, Leipzig

M. P. Lutz, Saarbrücken

H. Matsubara, Chiba

D. Müller, Marburg

M. Nakamura, Tokyo

A. Neesse, Göttingen

M. Pavel, Berlin

A. Perren, Bern

R.R. Plentz, Tübingen

J. Rosendahl, Leipzig

A. Shiotani, Kurashiki

T. Sugai, Morioka

A. Weber, Munich

\section{JGA Editorial Representatives}

Y. Kinoshita, Izumo

K. Higuchi, Osaka 
S. Karger

Medical and Scientific Publishers

Basel $\cdot$ Freiburg $\cdot$ Paris $\cdot$ London .

New York $\cdot$ Chennai $\cdot$ New Delhi $•$

Bangkok $\cdot$ Beijing $\cdot$ Shanghai $\cdot$ Tokyo .

Kuala Lumpur $\cdot$ Singapore $\cdot$ Sydney

\section{Disclaimer}

The statements, opinions and data contained in this publication are solely those of the individual authors and contributors and not of the publisher and the editor(s). The appearance of advertisements in the journal is not a warranty, endorsement, or approval of the products or services advertised or of their effectiveness, quality or safety. The publisher and the editor(s) disclaim responsibility for any injury to persons or property resulting from any ideas, methods, instructions or products referred to in the content or advertisements.

Drug Dosage

The authors and the publisher have exerted every effort to ensure that drug selection and dosage set forth in this text are in accord with current recommendations and practice at the time of publication. However, in view of ongoing research, changes in government regulations, and the constant flow of information relating to drug therapy and drug reactions, the reader is urged to check the package insert for each drug for any change in indications and dosage and for added warnings and precautions. This is particularly important when the recommended agent is a new and/or infrequently employed drug.
All rights reserved

No part of this publication may be translated into other languages, reproduced or utilized in any form or by any means, electronic or mechanical, including photocopying, recording, microcopying, or by any information storage and retrieval system, without permission in writing from the publisher or in the case of photocopying, direct payment of a specified fee to the Copyright Clearance Center (see 'General Information')

(c) Copyright 2015 by S. Karger AG

CH-4009 Basel (Switzerland)

Printed on acid-free and non-aging paper (ISO 9706)

\section{KARGER}


No. 1

Original Papers

1 Vitamin D Status and Adiposity in Pediatric Malabsorption Syndromes

Nwosu, B.U.; Maranda, L. (Worcester, Mass.)

8 Non-Celiac Gluten Sensitivity among Patients Perceiving Gluten-Related Symptoms

Capannolo, A.; Viscido, A.; Barkad, M.A.; Valerii, G.; Ciccone, F.; Melideo, D.; Frieri, G.; Latella, G. (L'Aquila)

14 Intestinal Endometriosis: Mimicker of Inflammatory Bowel Disease?

Guadagno, A.; Grillo, F.; Vellone, V.G.; Ferrero, S.; Fasoli, A.; Fiocca, R.; Mastracci, L. (Genoa)

22 Efficacy of Caraway Oil Poultices in Treating Irritable Bowel Syndrome - A Randomized Controlled Cross-Over Trial Lauche, R.; Janzen, A.; Lüdtke, R.; Cramer, H.; Dobos, G.; Langhorst, J. (Essen)

32 Carbohydrate Malabsorption and Putative CarbohydrateSpecific Small Intestinal Bacterial Overgrowth: Prevalence and Diagnostic Overlap Observed in an Austrian Outpatient Center

Enko, D.; Kriegshäuser, G.; Kimbacher, C.; Stolba, R. (Steyr); Mangge, H. (Graz); Halwachs-Baumann, G. (Steyr)

39 Granulocyte/Monocyte Adsorptive Apheresis in Moderate to Severe Ulcerative Colitis - Effective or Not? Kruis, W.; Nguyen, P.; Morgenstern, J. (Cologne)

45 Galectin-3 Modulates Experimental Colitis

Lippert, E.; Stieber-Gunckel, M.; Dunger, N.; Falk, W.; Obermeier, F.; Kunst, C. (Regensburg)

\section{No. 2}

JGA Topic Reviews

73 Perspectives for Regenerative Medicine in the Treatment of Inflammatory Bowel Diseases

Okamoto, R.; Watanabe, M. (Tokyo)

99 Current Topics of Strategy of NSAID-Induced Small Intestinal Lesions

Edogawa, S.; Takeuchi, T.; Kojima, Y.; Ota, K.; Harada, S.; Kuramoto, T.; Narabayashi, K.; Inoue, T.; Higuchi, K. (Osaka)

Original Papers

55 Current Status of Five Different Regimens for Empiric First-Line Helicobacter pylori Eradication in Turkey Gungor, G. (Konya); Baglıcakoglu, M. (Çorum); Kayacetin, E. (Ankara); Biyik, M.; Ucar, R.; Goktepe, H.; Ataseven, H.; Demir, A. (Konya)
60 Association between Diverticular Disease and Pre-Neoplastic Colorectal Lesions in an Urban African-American Population Ashktorab, H.; Panchal, H.; Shokrani, B.; Paydar, M.; Sanderson, A.; Lee, E.L.; Begum, R.; Haidary, T.; Laiyemo, A.O.; McDonald-Pinkett, S.; Brim, H.; Nouraie, M. (Washington, D.C.)

66 Appropriateness of Repeating Helicobacter pylori Culture and Susceptibility Testing Following Failure of Individualized Antibiotic Therapy

Boltin, D. (Petah Tikva/Tel Aviv); Ben-Zvi, H.; Perets, T.T. (Petah Tikva); Gingold-Belfer, R.; Dickman, R.; Niv, Y. (Petah Tikva/Tel Aviv)

78 Prevalence of Primary Resistance of Helicobacter pylori to Clarithromycin and Levofloxacin in Southern Spain Navarro-Jarabo, J.M. (Marbella/Madrid); Fernández-Sánchez, F.; Fernández-Moreno, N. (Marbella); Hervas-Molina, A.J. (Córdoba); Casado-Caballero, F. (Granada); Puente-Gutierrez, J.J. (Andujar); Pallares-Manrique, H. (Huelva); Rodríguez-Ramos, C. Fernández-Gutierrez, C. (Cádiz); Pérez-Aisa, A. (Marbella); Rivas-Ruiz, F. (Madrid/Marbella); Montiel Quezel-Guerraz, N. (Marbella)

83 Serum REG3alpha and C-Reactive Protein Levels in Crohn's Disease Patients Undergoing Immunoablation and Autologous Hemopoetic Stem Cell Transplantation in the ASTIC Trial

Greuter, T.; Lang, S. (Zurich); Holler, E. (Regensburg); Hawkey, C.J. (Nottingham); Rogler, G.; Biedermann, L. (Zurich) ASTIC trial group

90 Novel Prokinetic Acotiamide Reduces Transient Lower Esophageal Sphincter Relaxation in Healthy Subjects Yamashita, H.; Kanamori, A.; Fukuchi, T.; Tsujimae, M.; Koizumi, A.; Iwatsubo, T.; Koyama, S.; Eguchi, T.; Ubukata, S.; Fujita, M.; Okada, A. (Osaka)

108 Recombinant Thrombomodulin Modulates Murine Colitis Possibly via High-Mobility Group Box 1 Protein Inhibition Ueda, T.; Higashiyama, M.; Narimatsu, K.; Yasutake, Y.; Kurihara, C.; Okada, Y.; Watanabe, C.; Yoshikawa, K.; Maruta, K.; Komoto, S.; Tomita, K.; Nagao, S.; Hokari, R.; Miura, S. (Saitama)

\section{No. 3}

Invited Review

175 New Advances in the Treatment of Metastatic Pancreatic Cancer

Schober, M. (Halle); Javed, M.A. (Liverpool); Beyer, G. (Greifswald); Le, N. (Budapest); Vinci, A. (Pavia); Sund, M. (Umea); Neesse, A. (Göttingen); Krug, S. (Halle)

Editorials

171 Autoimmune Pancreatitis: Avoiding Unnecessary Procedures by Following International Consensus Guidelines Beyer, G. (Greifswald); Ellenrieder, V.; Neesse, A. (Göttingen)

173 The Need for Resistance Surveillance and Antimicrobial Susceptibility Testing of Helicobacter pylori Glocker, E.-O. (Freiburg)

\section{KARGER}

E-Mail karger@karger.com www.karger.com (c) 2015 S. Karger AG, Basel

Access to full text and tables of contents, including tentative ones for forthcoming issues: www.karger.com/dig_issues 
Original Papers

121 Does Pre-Operative Multiple Immunosuppressive Therapy Associate with Surgical Site Infection in Surgery for Ulcerative Colitis?

Uchino, M.; Ikeuchi, H.; Bando, T.; Hirose, K.; Hirata, A.; Chohno, T.; Sasaki, H.; Takahashi, Y.; Takesue, Y.; Hida, N.; Hori, K.; Nakamura, S. (Hyogo)

130 Tissue Inhibitors of Metalloproteinase-1 and 2 and Obesity Related Non-Alcoholic Fatty Liver Disease: Is There a Relationship?

Abdelaziz, R.; Elbasel, M.; Esmat, S.; Essam, K.; Abdelaaty, S. (Cairo)

138 Unnecessary Procedures and Surgery in

Autoimmune Pancreatitis

Manser, C.N.; Gubler, C.; Müllhaupt, B.; Bauerfeind, P. (Zurich)

147 Clinical Features of Refractory Pouchitis with Penetrating Lesions and the Efficacy of Infliximab Treatment for Patients with Ulcerative Colitis after Restorative Proctocolectomy Uchino, M.; Ikeuchi, H.; Bando, T.; Hirose, K.; Hirata, A.; Chohno, T.; Sasaki, H.; Horio, Y.; Takahashi, Y.; Takesue, Y.; Hida, N.; Hori, K.; Nakamura, S. (Hyogo)

156 Impact of Bowel Preparation with Low-Volume (2-Liter) and Intermediate-Volume (3-Liter) Polyethylene Glycol on Colonoscopy Quality: A Prospective Observational Study Cheng, C.-L.; Kuo, Y.-L.; Liu, N.-J.; Lin, C.-H. (Taoyuan City); Tang, J.-H. (Mailiao Township); Tsui, Y.-N.; Lee, B.-P.; Su, M.-Y.; Chiu, C.-T. (Taoyuan City)

165 Difference in Outcomes of Rectal Foreign Bodies between Males and Females: A Retrospective Analysis of a National Inpatient Database in Japan

Odagiri, H. (Tokyo/Saitama); Yasunaga, H.; Matsui, H.; Fushimi, K.; Iizuka, T.; Kaise, M. (Tokyo)

\section{No. 4}

Original Papers

185 Risk Factors for Polyautoimmunity among Patients with Celiac Disease: A Cross-Sectional Survey

Demirezer Bolat, A.; Akın, F.E.; Tahtacı, M.; Tayfur Yürekli, Ö.; Köseoğlu, H.; Erten, Ş.; Başaran, M.; Selvi, E.; Büyükaşık, Ş.; Ersoy, O. (Ankara)

192 Hsp27 Acts as a Master Molecular Chaperone and Plays an Essential Role in Hepatocellular Carcinoma Progression Cheng, J.; Lv, Z.; Weng, X.; Ye, S.; Shen, K. (Hangzhou); Li, M. (Beijing); Qin, Y.; Hu, C.; Zhang, C.; Wu, J.; Zheng, S. (Hangzhou)

203 Effect of Chondroitin Sulphate on Pro-Inflammatory Mediators and Disease Activity in Patients with Inflammatory Bowel Disease

Linares, P.M.; Chaparro, M.; Algaba, A.; Román, M.; Moreno Arza, I.; Abad Santos, F.; Ochoa, D.; Guerra, I.; Bermejo, F.; Gisbert, J.P. (Madrid)

211 Rapamycin Improves Mortality Following Intestinal Ischemia-Reperfusion via the Inhibition of Remote Lung Inflammation in Mice Iida, T.; Takagi, T.; Katada, K.; Mizushima, K.; Fukuda, W.; Kamada, K.; Uchiyama, K.; Handa, O.; Ichikawa, H.; Naito, Y.; Itoh, Y. (Kyoto)

220 Conscious Sedation Using Midazolam and Sequential Flumazenil in Cirrhotic Patients for Prophylactic Endoscopic Variceal Ligation Kim, S.I.; Jin, Y.-J.; Lee, S.H.; Lee, J.-W.; Lee, D.H.; Lee, D. (Incheon)

227 Evaluation of the Expanded Criteria of Endoscopic Submucosal Dissection for Early Gastric Cancers: A Meta-Analysis

Dai, J.; Huang, X.; Lu, B.; Jin, H.; Meng, L. (Hangzhou)

236 Acknowledgement to Referees 